\title{
PENATALAKSANAAN DIET PADA NEFROPATI DIABETIK
}

\author{
Triyani Kresnawan ${ }^{1}$ dan Ferina Darmarini ${ }^{1}$ \\ Instalasi Gizi Rumah Sakit Dr. Cipto Mangunkusumo (RSCM)
}

\begin{abstract}
ABSTRAK
One of the complication of diabetes mellitus is nephropathy diabetic, if this situation is not cured properly it tends to develop the end stage of renal failure. The objectives of this diet management in patients with nephropathy diabetic are to reduce progression of renal damage, maintain the nutritional status of the patient, control blood glucose, lipid serum and maintain electrolyte and fluid balance. Nutrient requirement of nephropathy diabetic patients should contain: protein $0.8 \mathrm{~g} /$ $\mathrm{kg} / \mathrm{body}$ weigh/day. But if patients suffered of end stage of renal failure $0.8 \mathrm{~g} / \mathrm{kg}$ body weigh/day, in the case of dialysis the protein need is $1-1.2 \mathrm{~g} / \mathrm{kg}$ body weigh/day. For energy requirement they need $35 \mathrm{kcal} / \mathrm{kg}$ body weigh/day, with the carbohydrate $60 \%$ from total energy need, fat should be $30 \%$ total energy need contain poly unsaturated fatty acid and mono unsaturated fatty acid. For mineral, natrium $(\mathrm{Na})$ is needed $1000-3000 \mathrm{mg} /$ day, whereas kalium $(\mathrm{K})$ is $40-70 \mathrm{mEq} /$ day $(1600-$ $2800 \mathrm{mg} /$ day). In conclusion, diet management is taking an important role to delay the progression of being end stage renal failure.
\end{abstract}

Keywords: nefropati diabetik, gagal ganjal terminal

\section{PENDAHULUAN}

$\mathrm{P}$ enyakit diibetes melitus yang tidak terkendali dengan baik dapat menimbulkan berbagai komplikasi/ penyulit, salah satunya penyakit gagal ginjal kronik yang dikenal dengan nefropati diabetik. Diramalkan oleh WHO bahwa 20 tahun kedepan penyakit diabetes melitus akan mengalami peningkatan jumlah penderita yang sangat pesat di dunia termasuk di Asia Tenggara, $20-30 \%$ pasien diabetes akan berkembang menuju nefropati. Nefropati diabetik, apabila tidak ditangani dengan baik dapat berkembang bertahap mulai dari tahap awal di mana terjadi ekskresi albumin yang abnormal sampai dengan gagal ginjal terminal (GGT).

Tujuan penatalaksanaan diet pada pasien nefropati diabetik adalah untuk mencegah progresivitas kerusakan ginjal, mempertahankan status gizi optimal, mengendalikan kadar glukosa darah, mengendalikan kadar lipida darah, mengendalikan tekanan darah, serta mempertahankan keseimbangan cairan dan elekrtolit ${ }^{(1.3)}$.

\section{Kebutuhan zat gizi}

Penatalaksanaan diet sangatlah penting untuk mencegah terjadinya nefropati diabetik lebih lanjut dan mencegah komplikasi penyakit lainnya. Zat gizi yang mendapat perhatian adalah ${ }^{(2)}$ :

Protein: Pembatasan protein pada pasien nefropati diabetik merupakan hal yang penting. Asupan protein lebih rendah dari diet diabetes pada umumnya. Protein dianjurkan sesuai dengan tingkatan penurunan fungsi ginjal. Pada saat ini anjuran asupan protein $0.8 \mathrm{gr} / \mathrm{kg} \mathrm{BB} / \mathrm{hari}$, kurang atau sama dengan 10\% dari total energi. Apabila terjadi penurunan fungsi ginjal lebih lanjut dimana fungsi ginjal sudah sangat buruk, ditandai dengan nilai glomerolus filtration rate (GFR)/creatinine clearance test (CCT) 10-15 ml/mt), maka asupan protein dianjurkan $0.6 \mathrm{gr} / \mathrm{kg} \mathrm{BB}$. Sekurang-kurangnya $50 \%$ berasal dari protein yang bernilai bernilai biologi tinggi. Pada berbagai penelitian, pemberian diet rendah protein bersamaan dengan pemberian asam amino esensial dan hormon eritropoetin pada pasien dengan nefropati diabetik, menunjukan penurunan perburukan 
fungsi ginjal dibanding dengan pasien yang diberi diet rendah protein saja.

Pada nefropati diabetik dimana pasien sudah menjalani terapi pengganti hemodialisis protein dianjurkan $1.2 \mathrm{gr} / \mathrm{kgBB} / \mathrm{hari}$, sedangkan jika pasien menjalani continuous ambulatory peritoneal dialysis (CAPD) protein dianjurkan $1.3-1.5 \mathrm{gr} / \mathrm{kg} \mathrm{BB} /$ hari atau sama dengan $\pm 20 \%$ dari total kalori

Energi: Kebutuhan energi untuk pasien nefropati diabetik, yaitu $35 \mathrm{kcal} / \mathrm{kgBB} /$ hari. Asupan energi yang adekuat bertujuan agar protein tidak dipecah menjadi sumber energi.

Karbohidrat: Karbohidrat yang dianjurkan adalah $60 \%$ dari total kalori. Penggunaan karbohidrat komplek tetap diutamakan. Pada diet nefropati diabetik, dengan pembatasan protein, dirasakan sulit untuk mencapai kebutukan kalori apabila menggunakan karbohidrat komplek saja. Oleh karena itu bahan makanan tinggi kalori rendah protein dari karbohidrat sederhana dapat diberikan untuk memenuhi kebutuhan kalori. Pemberian karbohidrat sederhana seperti gula dapat dikonsumsi bersamaan dengan makanan, atau dimasukan dalam makanan olahan. Anjuran diet pada pasien diabetes yang terbaru mengutamakan jumlah karbohidratnya, bukan jenisnya. Anjuran konsumsi sukrosa lebih liberal. Bukti menunjukkan bahwa penggunaan sukrosa sebagai bagian dari perencanaan makan pasien diabetes tidak memperburuk kontrol glukosa darah.

Penelitian di Pusat diabetes dan lipid RSCM tahun 1998 membuktikan tidak ada perbedaan yang bermakna pada glukosa darah dan trigliserida darah pasien diabetes tipe2 yang diberi $15 \%$ sukrosa dibanding dengan pasien yang mendapatkan diet dengan karbohidrat komplek. Anjuran konsumsi gula pada pasien diabetes tanpa komplikasi saat ini $5 \%$ dari total kalori. Pada pasien nefropati diabetik dengan terapi pengganti CAPD, $35 \%-40 \%$ karbohidrat berasal dari asupan makanan, sedangkan $15 \%$ sisanya berasal dari cairan peritoneal yang digunakan yaitu dektrosa.

Lemak: Lemak dianjurkan $30 \%$ dari total kalori. Persentase lemak lebih tinggi dari diet diabetes pada umumnya, hal ini dimaksudkan untuk mencukupi kebutuhan energi, karena sumber energi dari protein terbatas. Lemak diutamakan dari jenis tidak jenuh ganda maupun tunggal yaitu minyak jagung, minyak wijen, minyak zaitun. Asupan lemak jenuh dianjurkan kurang dari $10 \%$. Asupan kholesterol dianjurkan kurang dari $300 \mathrm{mg} / \mathrm{hari}$.

Garam (natrium): Anjuran asupan garam natrium $(\mathrm{Na})$ pasien nefropati diabetik berkisar antara 1000 - 3000 mg Na sehari, tergantung pada tekanan darah, ada tidaknya udema atau asites, serta pengeluaran urine sehari. Pada pasien nefropati diabetik yang sudah menjalani terapi pengganti hemodialisis kebutuhan natrium adalah $1000 \mathrm{mg}+2000 \mathrm{mg}$ apabila jumlah urine sehari $1000 \mathrm{ml}$.

Kalium: Kadar kalium darah harus dipertahankan dalam batas normal. Pada beberapa pasien, kadar kalium darah meningkat disebabkan karena asupan kalium dari makanan yang berlebihan atau obatobatan yang diberikan. Anjuran asupan kalium tidak selalu dibatasi, kecuali bila terjadi hiperkalemia yaitu kalium darah $>5.5$ $\mathrm{mEq}$, jumlah urine sedikit atau GFR/CCT kurang atau sama dengan $10 \mathrm{ml} / \mathrm{mt}$. Pada kondisi ini anjuran asupan kalium berkisar 40-70 mEq/hari (1600-2800 mg/hari) atau 40 $\mathrm{mg} / \mathrm{kgBB} / \mathrm{hari}$, hindari makanan tinggi sumber kalium. Pada nefropati diabetik dengan terapi pengganti hemodialisis kebutuhan kalium dapat dihitung berdasarkan pengeluaran urine sehari, yaitu kebutuhan dasar $2000 \mathrm{mg}+$ jumlah urine sehari. Obat pengikat kalium dapat diusulkan kepada dokter yang merawat.

Fosfor: Pada pasien nefropati diabetik, apabila terjadi hiperfosfatemia (kadar fosfat darah > $6 \mathrm{mg} / \mathrm{dl}$ ), asupan fosfor dari makanan harus dibatasi. Anjuran asupan pospor berkisar $8-12 \mathrm{mg} / \mathrm{kg} \mathrm{BB} /$ hari. kadang untuk mengontrol fosfat tidak mungkin hanya dengan diet. Obat pengikat fosfat diperlukan untuk mengikat fosfor dari makanan dalam saluran cerna yang bertujuan mencapai serum fosfat darah berkisar 4-6 mg/l. Agar obat pengikat fosfat bekerja optimal, maka harus diminum bersamaan dengan waktu makan. 
Kalsium: Keadaan hipokalsemia (kadar kalsium darah < $8.5 \mathrm{mg} / \mathrm{dl}$ ) kadang terjadi pada pasien nefropati diabetik. Penyebabnya adalah asupan kalsium yang tidak adekuat dan penyerapan yang tidak baik, oleh karena itu biasanya diberikan suplemen kalsium dalam bentuk tablet. Asupan kalsium yang dianjurkan adalah $1200 \mathrm{mg} / \mathrm{hari}$. Salah satu suplemen kalsium yang biasa diberikan adalah kalsium karbonat, selain sebagai suplemen naum juga berfungsi sebagai pengikat fosfat. Kadar kalsium darah yang diharapkan berkisar 8.5 - $11 \mathrm{mg} / \mathrm{dl}$ (4.6.5).

Cairan: Kebutuhan cairan perhari disesuaikan dengan jumlah urine sehari ditambah dengan pengeluaran cairan melalui keringat dan pernapasan $( \pm 500 \mathrm{ml})$

\section{Prosedur penyusunan diet.}

Penyusunan diet untuk pasien dianjurkan mengikuti langkah-langkah sebagai berikut:

- Tentukan kebutuhan zat gizi

- Lakukan recall kebiasaan makan

- Hitung jumlah protein yang bernilai biologi tinggi yang dibutuhkan

- Penuhi kekurangan kalori dari lemak dan karbohidrat yang mengandung rendah protein

- Susunan diet diusahakan mendekati kebiasaan makan pasien

- Buat contoh menu berdasarkan pilihan makanan dan pola makan

\section{Contoh bahan makanan:}

○ Protein bernilai biologi tinggi antara lain telur, susu, daging, ayam, ikan.

- Protein bernilai biologi rendah yaitu bahan makanan selain hewani seperti, kacang- kacangan, biji-bijian, umbi, tempe, tahu, beras, jagung, havermout, kentang, ubi.

- Sumber karbohidrat kompleks antara lain: kentang, ubi, singkong, beras havermout, jagung, bayam, sawi, kacang panjang.

- Sumber karbohidrat sederhana, seperti gula pasir, gula jawa, madu, sirup, permen, minuman ringan.

O Bahan makanan tinggi kalori rendah protein, seperti makanan / jajanan terbuat dari singkong, ubi, tepung maizena, tepung sagu / tapioka, sagu mutiara / pacar cina, agar-agar, getuk, keripik singkong, kolak biji salak, puding maizena,

- semprit sagu, kue lapis sagu, ongolongol sagu ambon, kue bagea, agaragar

O bening, selai, jelly, non dairy creamer, formula komersial rendah protein.

- Sumber lemak jenuh: mentega, minyak kelapa sawit, minyak kelapa, lemak susu.

- Sumber lemak tidak jenuh ganda: minyak jagung kedelai, minyak bunga matahari, minyak bunga safflower, mayonais.

- Sumber lemak tidak jenuh tunggal: minyak zaitun, alpukat, minyak kacang, adpokat

- Sumber kolesterol: lemak dari hewani seperi lemak daging, kuning telur, otak, susu full creaml.

- Sumber fosfor: susu dan hasil olahnya, hati, ikan sarden, udang, kacang kedelai, tahu, tempe, dan kacangkacangan.

- Sumber natrium: garam dapur, penyedap masakan/mono sodium glutamate (MSG), soda kue, zat pengawet (Na. Benzoat), makanan yang menggunakan bahan-bahan tersebut dalam pengolahannya.

○ Sumber kalium: pisang, tomat, alpukat, jambu biji, jeruk, rebung, bayam, daun pepaya, daun singkong, kentang, singkong, labu kuning, susu, santan kelapa.

\section{Contoh Kasus}

Seorang pasien wanita berumur 58 tahun dengan nefropati diabetlk. Tinggi badan 148 $\mathrm{cm}$, berat badan $49 \mathrm{~kg}$ dengan edema pada kaki. Berat badan idealnya $48 \mathrm{~kg}$. Hasil pemeriksaa laboratorium: $\mathrm{Hb}=7,4 \mathrm{mg} / \mathrm{dL}$, ureum = $186 \mathrm{mg} / \mathrm{dL}$, kreatinin $=3,1 \mathrm{mg} / \mathrm{dL}$, kolesterol = $286 \mathrm{mg} / \mathrm{dL}$, trigliserida $=182 \mathrm{mg} /$ $\mathrm{dL}$, asam urat $=9,9 \mathrm{mg} / \mathrm{dL}$, gula darah $\mathrm{N}=$ 286, $\mathrm{PP}=381 \mathrm{mg} / \mathrm{dL}$, Natrium = $137 \mathrm{mg} / \mathrm{dL}$, 
kalium $=5,9 \mathrm{mg} / \mathrm{dl}$. Tekanan darah 170/100

$\mathrm{mmHg}$.

Kebutuhan Zat Gizi

$\begin{array}{lc}\text { Zat Gizi } & \text { Kebutuhan } \\ \text { Kalori } & 1700 \\ \text { Protein } & 40 \mathrm{~g} \\ \text { Protein Hewani } & 20-26 \mathrm{~g} \\ \text { Lemak } & 60 \mathrm{~g} \\ \text { Karbohidrat } & 253 \mathrm{~g} \\ \text { Natrium } & 1000 \mathrm{mg} \\ \text { Kalium } & 600 \mathrm{mg} \\ \text { Kalsium } & 1200 \mathrm{mg} \\ \text { Fosfor } & 384-576 \mathrm{mg}\end{array}$

\author{
Dasar Perhitungan \\ $35 \mathrm{Kkal} / \mathrm{kg}$ BB ideal \\ $0,8 \mathrm{~g} / \mathrm{kg}$ BB ideal \\ $50-65 \%$ dari total protein \\ $30 \%$ dari total kalori \\ $59.9 \%$ dari total kalori \\ Ada udema \& acites \\ Ada hiperkalemia \\ sesuai anjuran \\ $8-12 \mathrm{mg} / \mathrm{kg} \mathrm{BB} / \mathrm{hari}$
}

\title{
Contoh Menu Sehari
}

\begin{tabular}{|l|l|l|}
\hline Waktu & Menu & Makanan Selingan \\
\hline Pagi & $\begin{array}{l}\text { Nasi } \\
\text { Telur dadar } \\
\text { Stup buncis }\end{array}$ & $\begin{array}{l}\text { Bubur sagu mutiara } \\
\text { Madu } \\
\text { (Jam 10.00) }\end{array}$ \\
\hline Siang & $\begin{array}{l}\text { Nasi } \\
\text { Ikan pepes } \\
\text { Sayur asem } \\
\text { Pepaya }\end{array}$ & $\begin{array}{l}\text { Puding maizena } \\
\text { Madu } \\
\text { (Jam 16.00) }\end{array}$ \\
\hline Malam & $\begin{array}{l}\text { Nasi } \\
\text { Ayam goreng } \\
\text { Capcay cah } \\
\text { Stup nenas }\end{array}$ & \\
\hline
\end{tabular}

\section{Penilaian Status Gizi}

Status gizi pasien dengan nefropati diabetik dapat dinilai berdasarkan pemeriksaan klinis, biokimia (albumin), antropometri (indeks massa tubuh), dan asupan makanan serta dengan cara subjektive global assessment (SGA), yaitu penilaian status gizi berdasarkan pemeriksaan fisik dan riwayat medis.

\section{KESIMPULAN}

1. Penatalaksanaan diet nefropati diabetik bertujuan mempertahankan status gizi seoptimal mungkin, menjaga agar tidak terjadi penurunan fungsi ginjal lebih lanjut, mengendalikan glukosa darah, mengendalikan tekanan darah serta menjaga keseimbangan cairan dan elektrolit.

2. Prisip pemberian diet adalah cukup energi yaitu $35 \mathrm{kcal} / \mathrm{kg}$. Protein disesuaikan dengan fungsi ginjal. Pada prinsipnya asupan protein moderat 0.8 $\mathrm{gr} / \mathrm{kg} \mathrm{BB}$. Apabila fungsi ginjal menurun lebih lanjut, dapat diberikan diet rendah protein $0.6 \mathrm{gr} / \mathrm{kg} \mathrm{BB}$.

3. Pada nefropati diabetik dengan terapi pengganti hemodialisis asupan protein dianjurkan $1.2 \mathrm{gr} / \mathrm{kg} \mathrm{BB}$ dengan energi $35 \mathrm{kcal} / \mathrm{kg} \mathrm{BB}$, sedangkan pada CAPD kebutuhan protein lebih tinggi lagi yaitu 
1.3 - $1.5 \mathrm{gr} / \mathrm{kg} \mathrm{BB}$ dengan energi 35 $\mathrm{kcal} / \mathrm{kgBB}$. Cairan CAPD diperhitungkan sebagai sumber energi, sehingga asupan $\mathrm{KH}$ dari makanan dan minuman disesuaikan.

4. Asupan cairan dan elektrolit disesuaikan dengan kondisi pasien.

\section{RUJUKAN}

1. Pedoman Diet Diabetes Melitus, FKUIRSCM, 2002.

2. William E.Mitch, Saulo Klahr. Handbook of Nutrition and the Kidney. 3 rd edition. Lippincott-Raven. Philadelphia. New York 1998.
3. Penyakit Ginjal Kronik \& Glomerulopati: Aspek klinik \& Patologi Ginjal. Pengelolaan hipertensi saat ini. PERNEFRI, 2003.

4. Nitya Nand, et al . Recent Advances in the Management of Diabetic Nephopathy. Journal Indian Academy of Clinical Medicine, 2001,2(1).

5. Henri Gin, et al. Which Diet For Diabetic Patient With Chronic Renal Failure?

6. Department of Diabetology Nutrition Nephrology, Universite de Bordeaux, France. Nephrol Dial Transplan 1999.

7. American Diabetes Association, Diabetic Nephropathy, Diabetes Care, 2003, 26, Suplement 1 .

\title{
Pada pasien dengan GGK dengan terapi pengganti CAPD
}

\author{
Energi dari cairan CAPD harus dihitung \\ Energi yang diserap: \\ $510 \mathrm{Kcal}$ (dekstrosa 1.5\%,1.5\%, 1.5\%, 4.25\%) \\ $570 \mathrm{Kcal}$ (dekstrosa 1.5\%, 2.5\%, 1.5\%, 4.25\%) \\ $660 \mathrm{Kcal}$ (dekstrosa 1.5\%, 4.25\%, 1.5\%, 4.25\%) \\ $680 \mathrm{Kcal}$ (dekstrosa 2.5\%, 2.5\%, 2.5\%, 4.25\%) \\ 770 Kcal (dekstrosa $2.5 \%, 4.25 \%, 2.5 \%, 4.25 \%$ ) \\ Cara menghitung TKK (CCT) \\ - Dengan rumus: \\ - $\quad$ TKK $=(140-$ umur $) \times$ Berat badan \\ Kreatinin plasma $\times 72$ \\ - Bila pasien wanita dikoreksi dengan 0.85 \\ - Dengan normogram \\ - Dengan urine tampung 24 jam
}

